Original Article

\title{
Impacts of mining on local fauna of wildlife in District Mardan \& District Mohmand Khyber Pakhtunkhwa Pakistan
}

\author{
Impactos da mineração na fauna local da vida selvagem nos Distritos de Mardan e de \\ Mohmand, Khyber Pakhtunkhwa, Paquistão

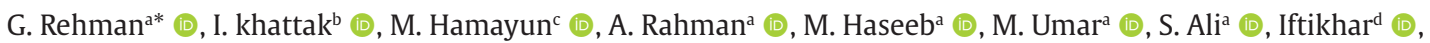 \\ W. A. Shams ${ }^{\mathrm{a}}(\mathbb{D})$ and R. Pervaiz ${ }^{\mathrm{a}}$ (1) \\ aDepartment of Zoology Abdul Wali Khan, University Mardan, KP, Pakistan

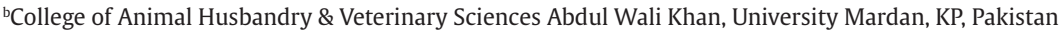 \\ 'Department of Botany Abdul Wali Khan, University Mardan, KP, Pakistan \\ dDepartment of Chemistry, University of Swabi, KP, Pakistan
}

\begin{abstract}
Mining is vital for human sustenance and a crucial sector in the state economy. However, its impacts on the environment and biodiversity cannot be underestimated. Which are potent to the attract government's attention. Environment and wildlife are subject to the harmful impacts of mining and its related activities. In this study, districts, namely Mardan and Mohmand have been targeted with respect to mining impacts. The assessment was carried out on wildlife adversely affected by the mining sector. The fauna has been keenly observed to bring the calculated risks and threat perception of the regional wildlife. Total 9 species of mammals, 21 species of birds, were recorded in District Mardan. While in District Mohmand 2 species of mammals, 9 species of birds, and 4 species of reptiles were studied. The Study explored that mining primarily responsible for land degradation. Which lead to food and agriculture losses. Several other factors like blasting, pollution, hunting, deforestation, habitat loss was also observed. Deforestation surfaced one of the major causes for extinction of fauna in the said region. preemptive measures are needed to seize the man-made catastrophe.
\end{abstract}

Keywords: mining, biodiversity, impacts, habitat destruction, blasting.

\section{Resumo}

A mineração é vital para o sustento humano e um setor crucial na economia do Estado. No entanto, seus impactos sobre o meio ambiente e a biodiversidade não podem ser subestimados, visto serem potentes para atrair a atenção do governo. O meio ambiente e a vida selvagem estão sujeitos aos impactos prejudiciais da mineração e de suas atividades relacionadas. Neste estudo, os distritos, nomeadamente Mardan e Mohmand, foram selecionados no que diz respeito aos impactos da mineração. A avaliação foi realizada em animais selvagens afetados negativamente pelo setor de mineração. A fauna tem sido observada atentamente para trazer os riscos calculados e a percepção de ameaça à vida selvagem regional. Um total de nove espécies de mamíferos, 21 espécies de pássaros, foi registrado no Distrito Mardan. Enquanto no Distrito Mohmand, duas espécies de mamíferos, nove espécies de pássaros e quatro espécies de répteis foram estudadas. O estudo explorou essa mineração que é principalmente responsável pela degradação do solo, acarretando perdas de alimentos e na agricultura. Vários outros fatores como explosões, poluição, caça, desmatamento, perda de habitat também foram observados. O desmatamento veio à tona como uma das principais causas de extinção da fauna da região, e tem-se que medidas preventivas são necessárias para dimensionar a catástrofe provocada pelo homem.

Palavras-chave: mineração, biodiversidade, impactos, destruição de habitat, detonação.

\section{Introduction}

Mining is a labor, activity, and industry involved in the extraction of minerals. It is the process of extracting useful minerals from the earth. Mining is an attractive business. Mining companies not only do, but also governments make money from taxes and licenses. Miners also make a living. The country's economy is based on the extraction of precious metals. It provides the government with significant revenue during taxation (Stephen et al., 2019). The outcomes of mining on the environment can occur at local, regional, and international tiers, through direct and oblique practices. Impacts can result in erosion, landslides, lack of biodiversity, or soil pollution, groundwater, and

*e-mail: Gauhar@awkum.edu.pk

Received: May 01, 2021 - Accepted: August 30, 2021 
surface water through chemical compounds launched from mining systems. Those techniques also influence the ecosystem from carbon emissions which impacts the pleasant of human lifestyles and biodiversity (Sonter et al., 2018). Mining and related activities are one of the major causes of environmental degradation of flora and fauna. As these activities' growth inside the context of the speedy use of herbal sources to fulfill the wishes of the market and local and national development. The hazard to natural world is growing daily. In addition to mining, large tracts of forest and flora and fauna habitat have been used for agriculture, industry, railways, and human settlements to the factor of devastation, fragmentation, and loss of habitat. Which additionally contributes to the whole lack of the environment. Lack of habitat and biodiversity in mining and related activities creates inequalities in ecosystems (Jadav and Thakar, 2018).

Mining produces a wide range of impacts that can affect the richness, abundance, and diversity of biotic communities, among the most important impacts of green removal which alters the availability of food, water, and wildlife habitat. Toxic effects on animal's drive from where heavy metals are extracted from the mines. The negative effects of mining on biodiversity depend largely on the state of pollution, the level of concentration in which it is found in the environment, and the type of nature itself. Some species are resistant to anthropogenic disorders. While some others will disappear completely in the polluted area (Tregubova et al., 2019). Mining contributes to pollution in large quantities in the environment by extracting a variety of heavy metals from mining operations. These heavy metals are deposited in the soil and water in the river, near the mining area. In the ground heavy metals create toxins in the soil leading to soil contamination. In soil these pollutants cause damage to plants and micro-organisms, which play an important role in the ecosystem (Laaouidi et al., 2020). The explosion of mines poses serious environmental problems. Animals are very sensitive to noise and leaves their habitat due to depletion of food sources. Explosions cause breeding differences in animals where animals use a different environment, and it seems that animals can be exposed to different species. (Huffman et al., 2010). The main effect of anthropogenic pollutants on wildlife is that wildlife ends up with a mine explosion in the mining area the animals migrate to another environment and are easily exposed to various predatory animals (Garcia et al., 2019). Mining is well-known for its negative effects on the environment, due to the accumulation of large amounts of debris in the soil. The negative impact of these mining activities in the surrounding areas is mainly due to the presence of a high number of cuts. These cuts often have negative effects on the natural vegetation they grow in, such as low $\mathrm{pH}$, concentration of toxic metals, low water retention capacity and low plant nutrient levels (Nouri and Haddioui, 2016). Wildlife can be affected directly by toxins and indirectly by creating mutations in biotic and abiotic factors. If the body is continuously exposed to specific toxins, the frequency of deformities can be raised in the affected areas of the mines. In addition, organisms that live on affected sites in the mines show high or elevated metabolic levels, poor body condition, reduced production
(Mochalova et al., 2019). Exposure of heavy metals with various anthropogenic substances can stop the growing bacteria in the area where important bacteria are lost which can help ride a nutrient bike without a negative impact on the ecosystem (Singh and Kamal, 2017).

Soil is a sensitive region because it can store pollutants produced via anthropogenic sports, along with mining and metallurgy, enterprise, agriculture, traffic, and so on. The removal of heavy metals from the soil is the result of methods between the factors of the soil and the metallic, inclusive of herbal, chemical and environmental procedures, however the soil is not always only a receptor for heavy metals, infected soil becomes a source of contamination of different organisms and meals chains (Gholizadeh et al., 2017). Concerning the impact of mining activities on animal communities, the presence of numerous levels of metals along with $\mathrm{cd}, \mathrm{cu}$, se, and $\mathrm{zn}$ in soil and water has been stated and acknowledged to reduce diversity and abundance in animal groups. The toxicity and endurance of heavy metals, which gather inside the environment due to various commercial activities, imply a serious environmental hassle worldwide. Demková et al. (2017) giant mineral extraction in mining regions has produced a huge quantity of waste and toxic waste from the surroundings. The threat of extinction is mounting with increasing levels of biodiversity that reduce species. With the increase in mining explosions, the distinct lifestyle of amphibians is particularly disrupted by voice function during feeding (Campos-Cerqueira and Aide, 2016).

Chemical pollution is a major threat to the health of wildlife. Biodiversity may affect a person's body processes before affecting a person's fitness which can lead to a decrease in human size. Individuals can produce different responses from different environmental stressors to their physical and physical environment (Kalantarzadeh et al., 2016) Mining can affect residential areas due to deforestation. The forest has been cleared to clear a mining route, and it is creating empty spaces. The loss of trees leads to the loss of bird's nesting areas, and mammals such as foxes and wolves do not like places close to humans and these species come from far away from the mines. Many birds and animals need a large area of undisturbed forest to survive, and the mines interfere with their movement and sometimes migration reduces their value and diversity in the mines and surrounding areas. Roads connecting mines lead to animal deaths due to accidents. According to Pangolin WWF's report 2019-20 (WWF, 2020), orangutan and other species have been reduced by traffic. If the roads are already built and make it easier to hunt wildlife. Mining leads to deterioration of soil quality, fertility, and toxicity. The main effects of mining are deforestation leading to the loss of plants and animals. It directly affects the ecosystem and its stability as many species are killed due to water and soil toxicity and habitat loss. The level of human activity has become so high that many of the world's ecosystems are somehow disturbed (Bloch et al., 2018). More than $40 \%$ of the world's arable land is directly disturbed and their natural production capacity is diverted, reduced, or destroyed (Boente et al., 2019).

Doubtless, that mining is important worldwide because it contribute greatly to the state economy. Simultaneously 
its impacts on environment and health of biodiversity especially wildlife cannot be ignored, which is of great concern for governments. In different stages environmental and wildlife health are affected depending on the severity of pollutants generated. The target study areas were district Mardan and district Mohmand. In which mining impacts were to be assessed on wildlife. Data recorded from September 2019 to May 2020 to focus on major threats responsible for extinction and endangerment. Study disclose that mining resulted in land degradation which led to food and agriculture loss. Several other factors like blasting, pollution, hunting, deforestation, habitat loss was observed. But the root cause of extinction includes mining related vast deforestation.

\section{Materials and Methods}

\subsection{Study area}

\subsection{District Mardan}

The learning process changed into performed in four fundamental mining regions in district Mardan tehsil katlang, specifically, babozai, shamozai, Mian khan, sangao. The mining activities are deed for takin-out methods of mined substances which include limestones, bentonite, and lignite. All the 4 mines are opencast mines effects into that leader lack of habitats with the aid of taking-out process of mined substances and dumping of waste materials in open get onto land. These mines are positioned inside the northeast part of Mardan. Mardan District lies between latitude $34^{\circ} 05^{\prime}$ to $34^{\circ} 32^{\prime}$ North and longitude $71^{\circ} 48^{\prime}$ to $72^{\circ} 25^{\prime}$ East. It is far restricted at the north-east through Buner district, at the north and north-west by means of Malakand stored safe place, at the south-east via Swabi, at the south by Nowshera district and at the west by means of charsadda district. General region of the district is 1632 square kilometers (Figure 1)

Summer season is hot and high temperature has been observed from May to July. The temperature reaches to its maximum (i.e., $40-48^{\circ} \mathrm{C}$ ) in the month of June. The coldest months are December and January in which the temperature falls to the average $2.09{ }^{\circ} \mathrm{C}$. Most of the rainfall occurs in the month of July, August, December, and January. The maximum rainfall recorded for the month of August is $125.85 \mathrm{~mm}$. The relative humidity is quiet high throughout the year with maximum (i.e., 73.33\%) humidity recorded in December. These mines are very close to the Khyber-Pakhtunkhwa Forest department (babozai Garhi sakra range wildlife division Mardan) which is the only habitat in these area for wildlife.

\subsection{District Mohmand}

The study was conducted in two major mining areas in tehsil prang ghar district Mohmand Khyber Pakhtunkhwa

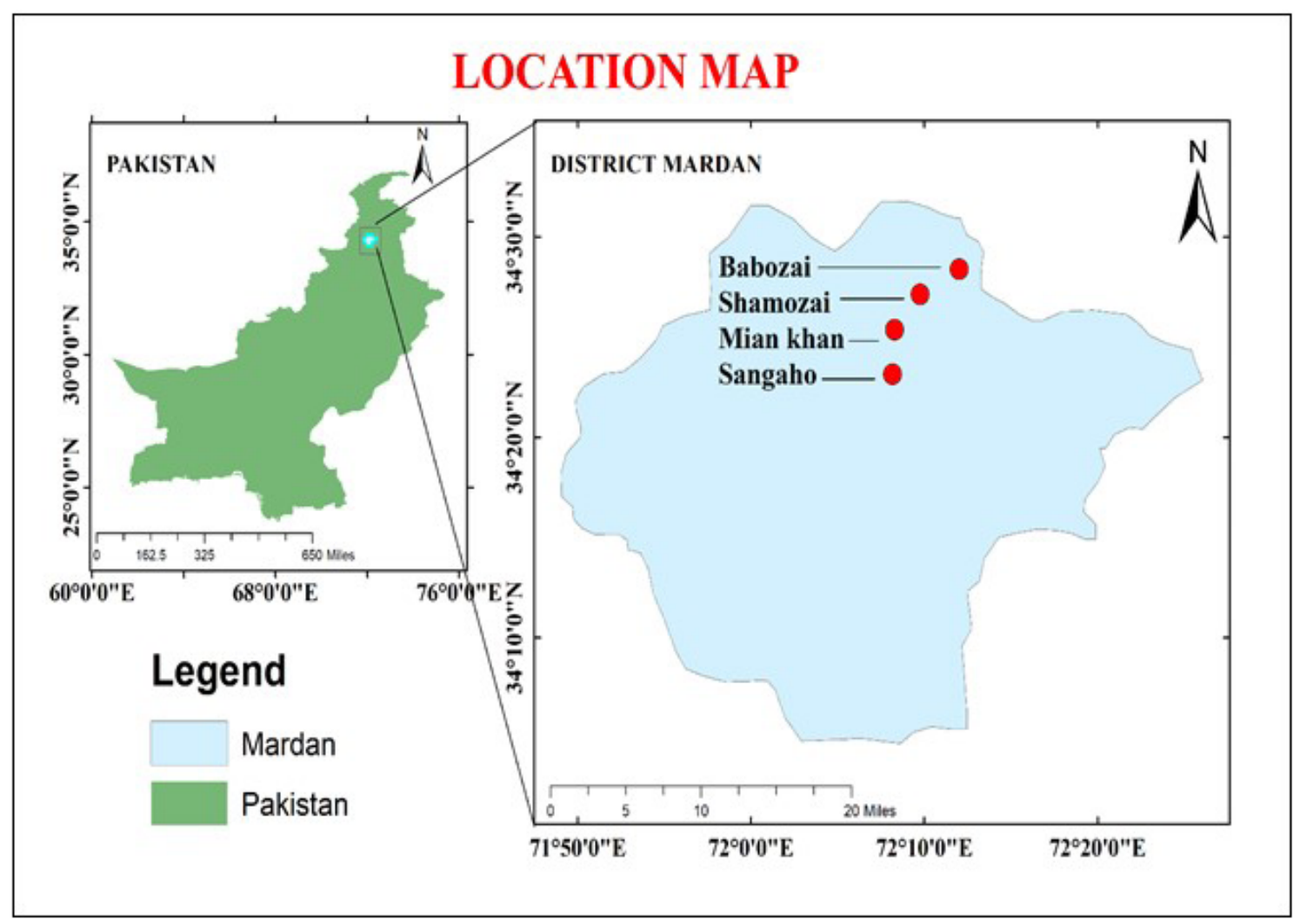

Figure 1. Show the observed study area of tehsil katlang district Mardan KP 
Pakistan. The total population of area is 35,290. Humidity is $37 \%$. Wind $14 \mathrm{~km} / \mathrm{h}$. temperature were recorded at the time of adventure $12 \mathrm{C}$. The two mining areas at the longitude $71^{\circ} 35^{\prime} 30.28^{\prime \prime}$, and $71^{\circ} 36^{\prime} 43.59$ "E (Figure 2)

Summer season is warm and high temperature has been discovered from May to July. The temperature reaches to its most (i.e., $38-43^{\circ} \mathrm{C}$ ) within the month of June. The coldest months are December and January wherein the temperature falls to the common $0-1{ }^{\circ} \mathrm{C}$.

\subsection{Sampling method}

Field studies (15th trip) are conducted periodically during the winter and summer. Data and literature were collected from various sources. Information relating to the health status of the inhabitants and the social and economic impacts were collected using structured questionnaires. Respondents included randomly selected miners and the head of households living in the mining areas. The current study aims to study the effects of mining on the biodiversity of the area. It also focuses on other long-term mining impacts in the study area such as blasting, pollution, hunting, deforestation, habitat loss etc.

Data were collected using direct and indirect methods to study the current state of wildlife in the area. Direct data were collected by visiting the study area once a day very early at 8:00 am until sunset. The bird's animals were observed using binoculars and each bird's state was described as follows.
M; Migration, Rs; Resident, C; Normal, R; Normal, No (c); number in the control area, No (m); Number in the mining area.

In the collection of indirect data, Hunters, wildlife workers, locals, Forms, and other knowledgeable people are asked about the status of birds, reptiles, etc. Variety of learning environment.

\section{Results}

In this study 09 species of mammals, 21 species of birds were recorded, in District Mardan. Which is a different order with families. In the Mohmand region 02 species of mammals, 04 species of reptiles and 09 species of birds were recorded. The fauna of the study areas was not rich due to mining activity, hunting and other environmental problems.

\subsection{Mammalian and Birds Fauna in District Mardan}

\subsection{Mammals}

The mammals found have been goral, porcupine, monkey, wild goat, jackal, mongoose, hare, and bat inside the Mardan location. Types are shown in (Table 1; Figure 3). These species have been found to be under threat. The main reasons of species decline within the look at place

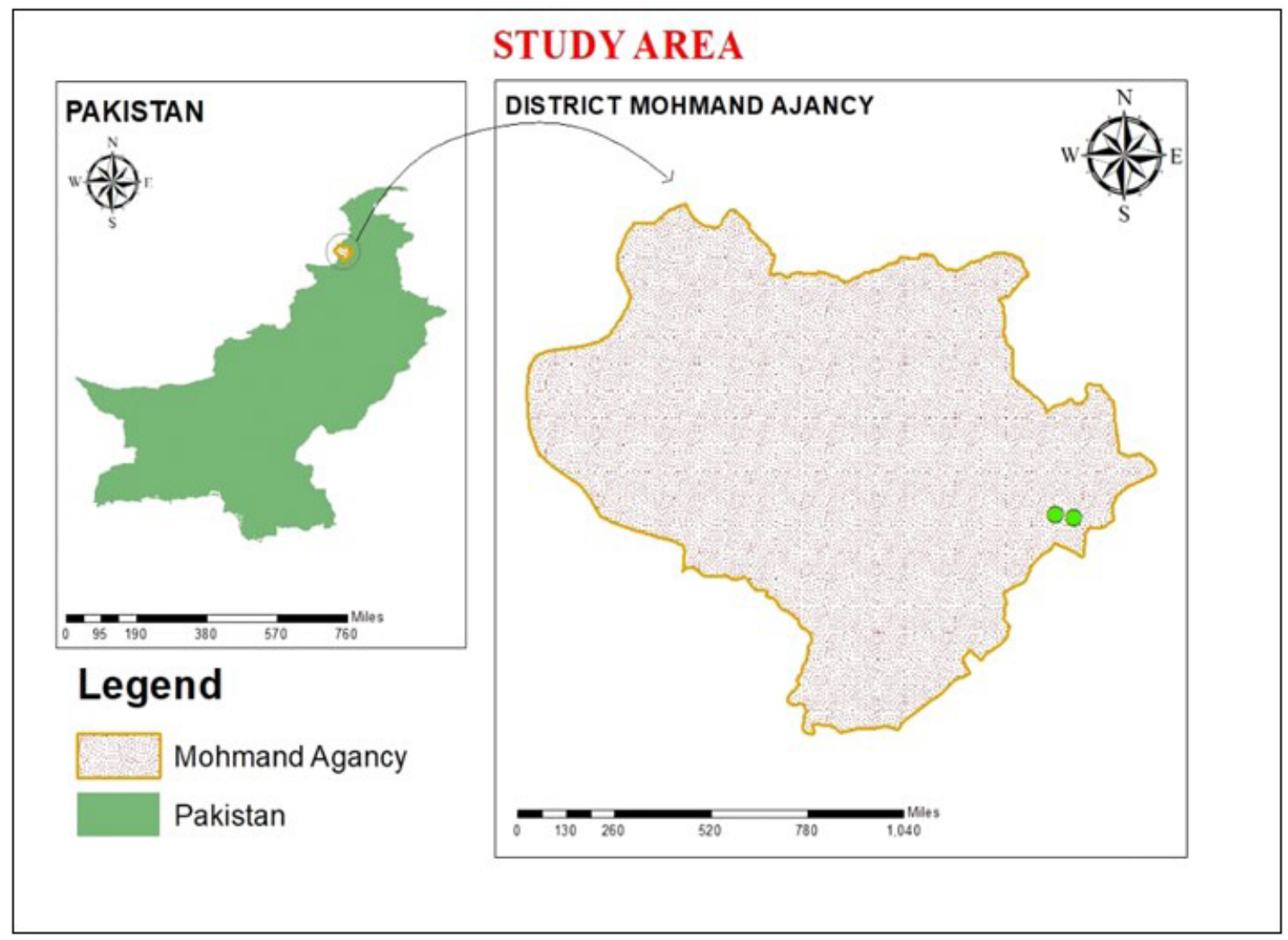

Figure 2. Show the observed study area of tehsil prang ghar district Mohmand KP. 
Table 1. Mammal's species recorded in Tehsil katlang District Mardan.

\begin{tabular}{|c|c|c|c|c|c|c|}
\hline S. No & ORDER & FAMILY & LOCAL NAME & $\begin{array}{c}\text { SCIENTIFIC } \\
\text { NAME }\end{array}$ & $\begin{array}{c}\text { No (IN } \\
\text { CONTROL } \\
\text { AREA) }\end{array}$ & $\begin{array}{c}\text { No (IN MINING } \\
\text { AREA) }\end{array}$ \\
\hline 1 & Artiodactyla & Bovidae & Goral & $\begin{array}{c}\text { Naemorhedus } \\
\text { Goral }\end{array}$ & 41 & 30 \\
\hline 2 & $\ldots \ldots \ldots$ & $\ldots \ldots \ldots$ & Wild goat & Capra aegagrus & 11 & 2 \\
\hline 3 & …........... & …........... & $\begin{array}{l}\text { Mountain } \\
\text { sheep }\end{array}$ & Ovis ammon & 15 & 6 \\
\hline 4 & Carniora & Canidae & Jakal & Canis aureus & 59 & 40 \\
\hline 5 & $\ldots \ldots \ldots$ & Herpestidae & Mangoos & $\begin{array}{l}\text { Herpestes } \\
\text { edwardsii }\end{array}$ & 21 & 13 \\
\hline 6 & Largomorpha & Lepodridae & Hare & $\begin{array}{c}\text { Lepus } \\
\text { negricollis }\end{array}$ & 27 & 22 \\
\hline 7 & Primates & Cercopithecidae & Monkey & $\begin{array}{c}\text { Macacca } \\
\text { mulatta }\end{array}$ & 80 & 57 \\
\hline 8 & Rodenta & Hystricidae & percupine & Hystrix indica & 31 & 20 \\
\hline 9 & Chiroptera & Microchiroptera & Bat & Chiroptera & 17 & 6 \\
\hline
\end{tabular}

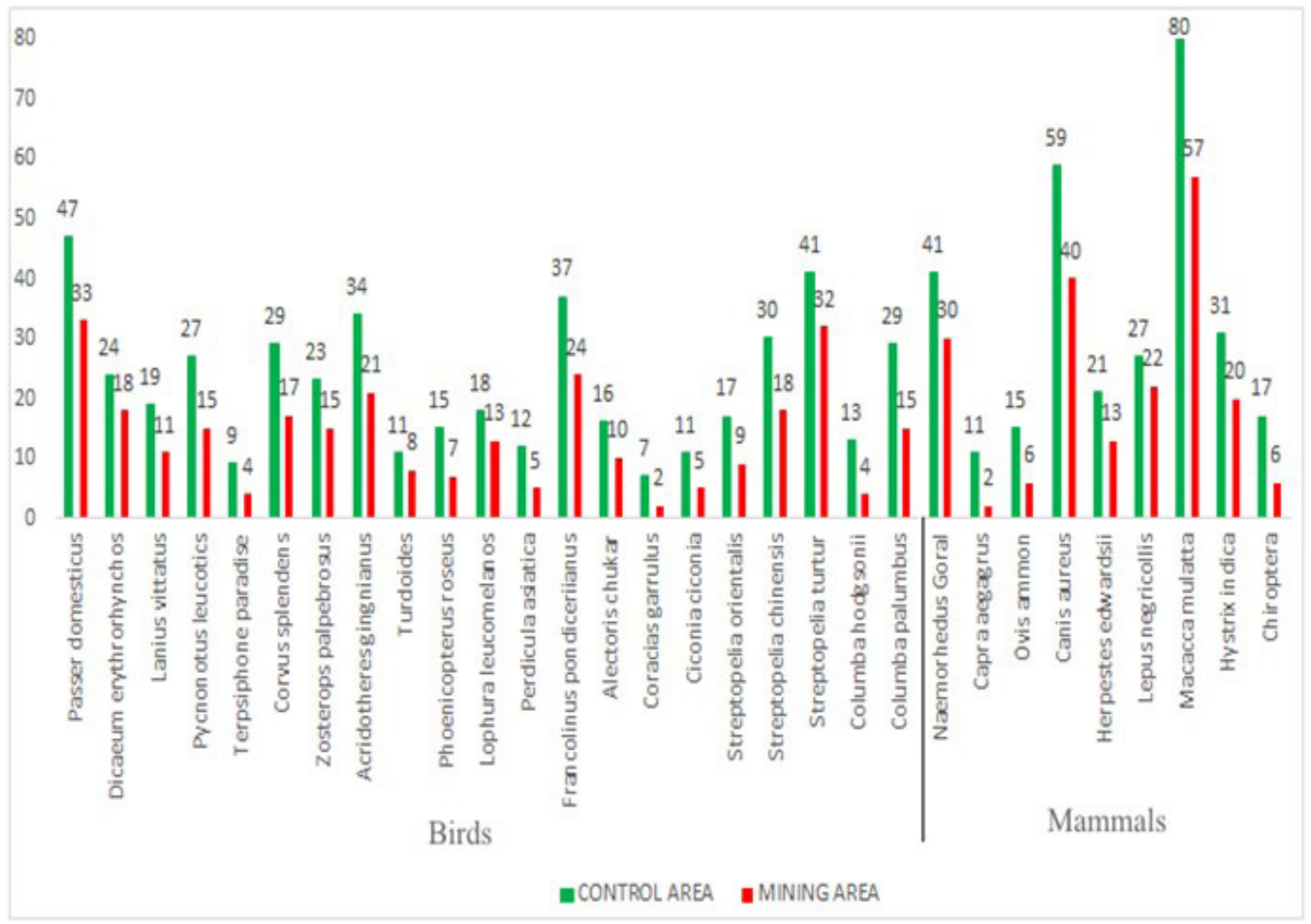

Figure 3. This graphical analysis shows the abundance of the wild species Birds and Mammals in Control and Mining Areas.

are mine explosions, deforestation, overcrowding and searching, habitat loss, pollution, and weather change.

The Mardan region, tehsil katlang mainly has a problem with mining, deforestation, overcrowding leading to danger and extinction of other species such as goral, wild goat etc.
In our study it was found that hunting and wildlife poaching are the leading causes of extinction of species, leading to the decline of species in the area. Overgrazing, population increase, mining, and deforestation result in the loss of habitat of those species as it provides haven 
and meals. Wildlife authorities are entreated to take the essential steps to save the natural world of the Mardan location, tehsil katlang.

\subsection{Birds}

During the study, 21 species were recorded under different orders and families (Table 2; Figure 3). The animals in the study area were not rich because of the explosion of mines, hunting, deforestation, and loss of habitat.
Food security and habitat play an important role in the diversity of birds, which are disrupted in the area due to mining, hunting and deforestation.

It was observed that birds were being hunted, and their proportions were very high due to overcrowding, and the mining industry. Passer domesticus, streptopelia Turtur, has been found in large numbers due to small hunting. Some birds have been found to be under fewer numbers due to mine explosions resulting in shelter for their breeding and other activities.

Table 2. Bird's species recorded in Tehsil katlang District Mardan.

\begin{tabular}{|c|c|c|c|c|c|c|}
\hline S. No & ORDER & FAMILY & $\begin{array}{l}\text { LOCAL } \\
\text { NAME }\end{array}$ & $\begin{array}{c}\text { SCIENTIFIC } \\
\text { NAME }\end{array}$ & $\begin{array}{c}\text { No (IN } \\
\text { CONTROL } \\
\text { AREA) }\end{array}$ & $\begin{array}{c}\text { No (IN MINING } \\
\text { AREA) }\end{array}$ \\
\hline 1 & Passeriformes & Passeridae & Chanchanra & $\begin{array}{c}\text { Passer } \\
\text { domesticus }\end{array}$ & 47 & 33 \\
\hline 2 & $\ldots \ldots \ldots$ & Dicaeidae & Chatai & $\begin{array}{c}\text { Dicaeum } \\
\text { erythrorhynchos }\end{array}$ & 24 & 18 \\
\hline 3 & $\ldots \ldots \ldots$ & Laniidae & Teghak & Lanius vittatus & 19 & 11 \\
\hline 4 & $\cdots \cdots \cdots$ & Pycnonotidae & Balbala & $\begin{array}{l}\text { Pycnonotus } \\
\text { leucotics }\end{array}$ & 27 & 15 \\
\hline 5 & $\ldots \ldots \ldots$ & Monarchidae & Partoghakhai & $\begin{array}{c}\text { Terpsiphone } \\
\text { paradise }\end{array}$ & 9 & 4 \\
\hline 6 & $\ldots \ldots \ldots$ & Corvidae & Kargha & $\begin{array}{c}\text { Corvus } \\
\text { splendens }\end{array}$ & 29 & 17 \\
\hline 7 & (n......... & Zosteropidae & Zyar chatai & $\begin{array}{c}\text { Zosterops } \\
\text { palpebrosus }\end{array}$ & 23 & 15 \\
\hline 8 & $\ldots \ldots \ldots$ & Sturnidae & Kharoo & $\begin{array}{l}\text { Acridotheres } \\
\text { gingnianus }\end{array}$ & 34 & 21 \\
\hline 9 & $\ldots \ldots \ldots$ & Leiothrichidae & Soorra & Turdoides & 11 & 8 \\
\hline 10 & Phoenicopteriforme & Phoenicopteridae & Deng & $\begin{array}{c}\text { Phoenicopterus } \\
\text { roseus }\end{array}$ & 15 & 7 \\
\hline 11 & Galliformes & Phasianidae & Taroo & $\begin{array}{c}\text { Lophura } \\
\text { leucomelanos }\end{array}$ & 18 & 13 \\
\hline 12 & (n........ & $\ldots \ldots \ldots$ & Batair & $\begin{array}{l}\text { Perdicula } \\
\text { asiatica }\end{array}$ & 12 & 5 \\
\hline 13 & (n........ & (n........ & Tanzara & $\begin{array}{c}\text { Francolinus } \\
\text { pondiceriianus }\end{array}$ & 37 & 24 \\
\hline 14 & $\ldots \ldots \ldots$ & $\ldots \ldots \ldots$ & Zarka & Alectoris chukar & 16 & 10 \\
\hline 15 & Coraciiformes & Coraciidae & Shentagh & $\begin{array}{l}\text { Coracias } \\
\text { garrulus }\end{array}$ & 7 & 2 \\
\hline 16 & $\ldots \ldots \ldots \ldots$ & $\ldots \ldots \ldots$ & Zanrai & Ciconia ciconia & 11 & 5 \\
\hline 17 & Columbiformes & Columbidae & Karkorai & $\begin{array}{l}\text { Streptopelia } \\
\text { orientalis }\end{array}$ & 17 & 9 \\
\hline 18 & ............. & $\cdots \cdots \cdots$ & Kautara & $\begin{array}{l}\text { Streptopelia } \\
\text { chinensis }\end{array}$ & 30 & 18 \\
\hline 19 & (n........ & 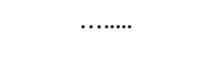 & $\begin{array}{l}\text { Kanra } \\
\text { kutara }\end{array}$ & $\begin{array}{l}\text { Streptopelia } \\
\text { turtur }\end{array}$ & 41 & 32 \\
\hline 20 & (n......... & $\ldots \ldots \ldots$ & $\begin{array}{l}\text { Tapasai } \\
\text { kautara }\end{array}$ & $\begin{array}{l}\text { Columba } \\
\text { hodgsonii }\end{array}$ & 13 & 4 \\
\hline 21 & (........... & $\ldots \ldots \ldots$ & $\begin{array}{c}\text { Shna } \\
\text { kautara }\end{array}$ & $\begin{array}{l}\text { Columba } \\
\text { palumbus }\end{array}$ & 29 & 15 \\
\hline
\end{tabular}




\subsection{Mammals, birds, and reptile's fauna of District Mohmand}

In district Mohmand 02 species of mammals, 04 species of reptiles and 09 species of birds were recorded. Which belong to different family and order. The fauna of the target areas was unrich due to the mining activity, hunting and other environmental problems. Hunting, shooting, and trapping of untamed fauna, vast grazing, deforestation, and lack of habitat are the primary reasons of species extinction within the district Mohmand. Feeding and habitat availability play important role in the diversity of birds, which are disturbed in this area due to hunting and deforestation.

The fauna of birds, mammals and reptiles of district Mohmand are shown in (Tables 3,4, 5; Figure 4).

\subsection{Data analysis}

Records gathered all through the study period have been analyzed in a single point-to-time calculation calculator using the Z-number. This simple self-calculation calculator uses the Z-number and sample $(\mathrm{M})$ to generate human-mean interval estimates. Data analysis is shown in (Tables 6, 7).

\section{Discussion}

In the past ecosystem disruption was one of the major changes in the relationship between living things and their environment in relation to time and space. As nature reveals symmetry so, change occur in one factor directly or indirectly effect the next one. As organisms depend directly on the environment in which they are living so,

Table 3. Bird's species recorded in District Mohmand.

\begin{tabular}{|c|c|c|c|c|c|c|}
\hline S. No & ORDER & FAMILY & LOCAL NAME & $\begin{array}{c}\text { SCIENTIFIC } \\
\text { NAME }\end{array}$ & $\begin{array}{l}\text { No (IN } \\
\text { CONTROL } \\
\text { AREA) }\end{array}$ & $\begin{array}{c}\text { No (IN MINING } \\
\text { AREA) }\end{array}$ \\
\hline 1 & Passeriformes & Dicruridae & Black grodon & $\begin{array}{c}\text { Dicrurus } \\
\text { macrocerus }\end{array}$ & 49 & 32 \\
\hline 2 & $\ldots \ldots \ldots . . .$. & Pycnontidae & $\begin{array}{l}\text { Himalayan } \\
\text { bulbul }\end{array}$ & $\begin{array}{l}\text { Pycnonotus } \\
\text { leucogenys }\end{array}$ & 55 & 38 \\
\hline 3 & $\ldots \ldots \ldots . . .$. & Leiothrichidae & Brown babbler & $\begin{array}{l}\text { Turdoides } \\
\text { plebejus }\end{array}$ & 62 & 34 \\
\hline 4 & $\ldots$ & Muscicapidae & $\begin{array}{l}\text { Blue caped } \\
\text { resdstart }\end{array}$ & $\begin{array}{c}P . \\
\text { coeruleocephala }\end{array}$ & 43 & 31 \\
\hline 5 & ................. & Dicruridae & $\begin{array}{l}\text { Franted } \\
\text { pancolin }\end{array}$ & $\begin{array}{l}\text { Francolinus } \\
\text { pondicerianus }\end{array}$ & 60 & 53 \\
\hline 6 & ............... & Leiothrichidae & $\begin{array}{l}\text { Common } \\
\text { babbler }\end{array}$ & $\begin{array}{c}\text { Turdoides } \\
\text { caudata }\end{array}$ & 52 & 45 \\
\hline 7 & Pelecaniformes & Ardeidae & $\begin{array}{l}\text { Western reef } \\
\text { heron }\end{array}$ & Egretta gularis & 57 & 43 \\
\hline 8 & $\ldots$ & .............. & $\begin{array}{l}\text { Dimorphic } \\
\text { egret }\end{array}$ & $\begin{array}{c}\text { Egretta } \\
\text { dimorpha }\end{array}$ & 64 & 52 \\
\hline 9 & Charadriiformes & Charadriidae & $\begin{array}{l}\text { Red-wettled } \\
\text { lapwing }\end{array}$ & $\begin{array}{l}\text { Vanellus } \\
\text { indicus }\end{array}$ & 84 & 65 \\
\hline
\end{tabular}

Table 4. Reptile's species recorded in District Mohmand kp.

\begin{tabular}{|c|c|c|c|c|c|c|}
\hline S. No & ORDER & FAMILY & LOCAL NAME & $\begin{array}{c}\text { SCIENTIFIC } \\
\text { NAME }\end{array}$ & $\begin{array}{c}\text { No (IN } \\
\text { CONTROL } \\
\text { AREA) }\end{array}$ & $\begin{array}{c}\text { No (IN MINING } \\
\text { AREA) }\end{array}$ \\
\hline 1 & Squmata & Agamadea & Hardwickspinytailed & $\begin{array}{c}\text { Saara } \\
\text { hardwickii }\end{array}$ & 42 & 23 \\
\hline 2 & $\ldots \ldots .$. & Scincidea & Eutropis dissimilis & $\begin{array}{l}\text { Eutropis } \\
\text { dissimlis }\end{array}$ & 35 & 18 \\
\hline 3 & ......... & Scincidea & Chalcides ocellatus & $\begin{array}{l}\text { Chalcides } \\
\text { ocellatus }\end{array}$ & 26 & 9 \\
\hline 4 & $\ldots \ldots . .$. & Agamadea & Gardan lizard & $\begin{array}{l}\text { Caltotes } \\
\text { versicolor }\end{array}$ & 32 & 11 \\
\hline
\end{tabular}


Table 5. Mammal's species recorded in District Mohmand kp.

\begin{tabular}{ccccccc}
\hline S. No & ORDER & FAMILY & LOCAL NAME & $\begin{array}{c}\text { SCIENTIFIC } \\
\text { NAME }\end{array}$ & $\begin{array}{c}\text { No (IN } \\
\text { CONTROL } \\
\text { AREA) }\end{array}$ & $\begin{array}{c}\text { No (IN MINING } \\
\text { AREA) }\end{array}$ \\
\hline 1 & Carnivora & Canidea & Fox & Vulpes vulpes & 56 & 27 \\
2 & Chiroptera & Microchiroptera & Bats & Chiroptera & 28 & 16 \\
\hline
\end{tabular}

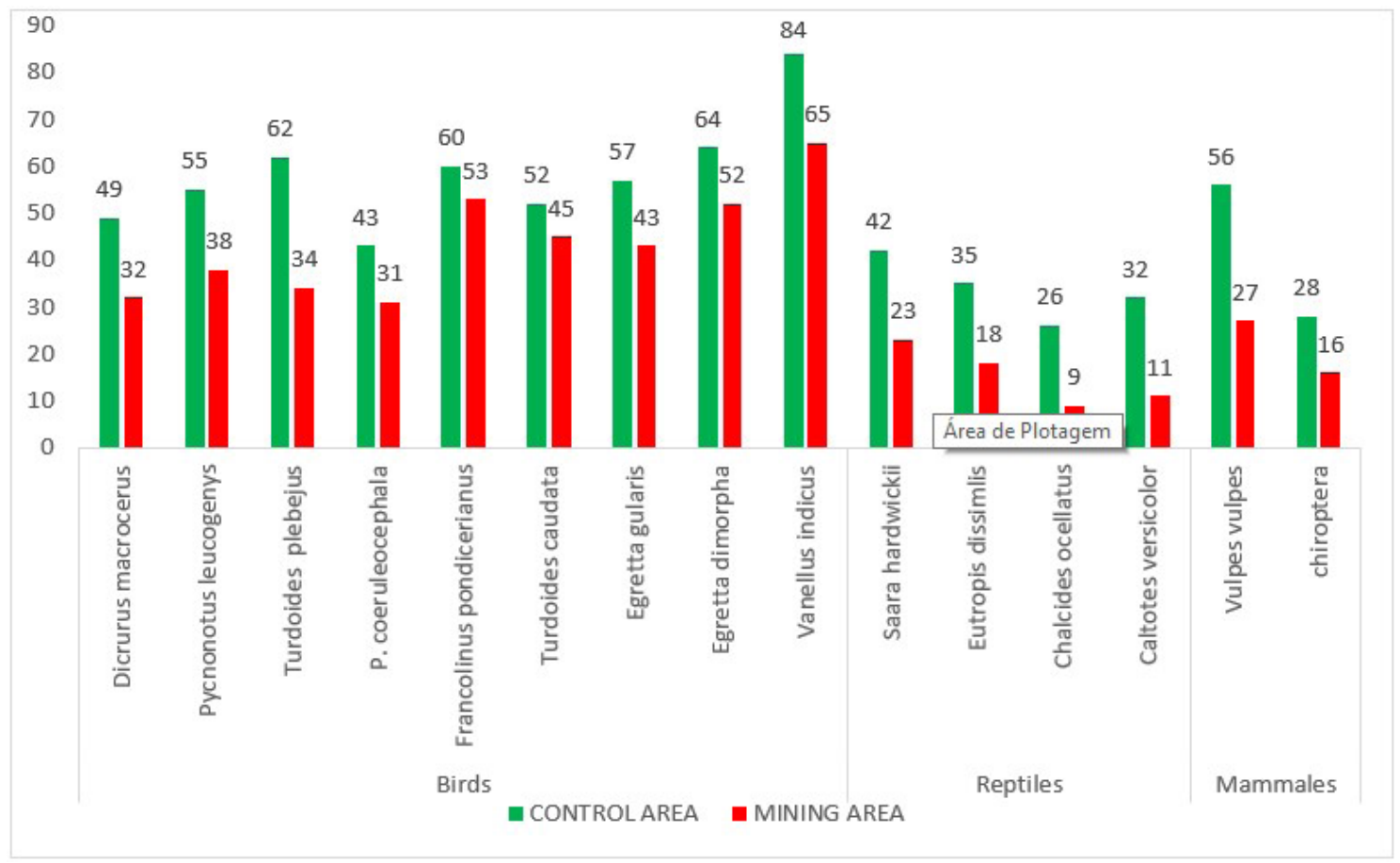

Figure 4. This graphical analysis shows the abundance of wildlife Birds, reptiles and mammals in control areas and mines.

the hazardous environment will ultimately affect the health of organism. The under-discussion study areas which consist of large- and small-scale mining sites for the extraction of different minerals and marbles heavily effect the native fauna. Before the installation of mining plants these areas were characterized for its rich fauna, but now the current scenario is totally changed. It is already clear that mining sites are not very much fertile in terms of tree or fauna because the installation of mining plants requires vast land areas for which large percentage of areas became the victim of deforestation due to which the local mass of organism decrease (Matthews et al., 2013).

Mining plants are very much centered at the extraction of diverse mineral resources through mining activities which is one of the key elements in environmental change. In flora and fauna habitats the gap from the habitat at that time has a terrible impact at the survival of treasured flora and fauna. The most common environmental impacts on the mining environment are deforestation, water scarcity, air pollution, water and soil and deforestation. These differences affect the survival of wildlife differently. The water available in the mines clogs the sites containing high amounts of heavy metals including $\mathrm{Ca}, \mathrm{Co} \mathrm{Cr}$. $\mathrm{Cu}, \mathrm{Fe}$, Mo. Ni, Pd, Sb, and zinc etc. Which ultimately mix with the freshwater present in canals, which directly affect the aquatic life. As a result of this contamination large amount aggregate in the organs of fishes, as fishes are used for food purpose which cause serious illness in human beings (Ali and Bibi, 2013).

Exclusion of organic matter in mining areas can occur in a variety of ways including inhalation of airborne dust, sewage infiltration, soil, and food chain. Mammals ingest the metals through diet. Food chain may be the most common way through which the absorption of heavy metals occurs in stepwise manner. The heavy metals accumulated in water absorbed by the plants roots and finally became the part of plant leaf and other different organs composition, animals including birds feed upon the leaves, seeds of trees. These metals target kidney liver etc. Different toxic substances are added via anthropogenic sources to the ecosystem that cause biomagnification and accumulate in tissue which cause tissue toxicity in biodiversity. Pollution is another major factor which heavily target the contamination of water and soil fauna (Akbari et al., 2018). 
Table 6. This table shows statistical analysis of wild animals In District Mardan.

\begin{tabular}{|c|c|c|c|}
\hline \multicolumn{4}{|c|}{ DISTRICT MARDAN } \\
\hline & NAME & $\begin{array}{l}\text { MEAN(95\% CONFIDENCE } \\
\text { INTERVAL) (C) }\end{array}$ & $\begin{array}{l}\text { MEAN(95\% CONFIDENCE } \\
\text { INTERVAL) (M) }\end{array}$ \\
\hline \multirow[t]{21}{*}{ BIRDS } & Passer domesticus & $47(45.48-48.52)$ & $33(31.48-34.52)$ \\
\hline & Dicaeum erythrorhynchos & $24(21.98-26.02)$ & $18(15.98-20.02)$ \\
\hline & Lanius vittatus & $19(16.47-21.53)$ & $11(08.47-13.53)$ \\
\hline & Pycnonotus leucotics & $27(25.48-28.52)$ & $15(13.48-16.52)$ \\
\hline & Terpsiphone paradise & $09(06.98-11.02)$ & $04(01.98-06.02)$ \\
\hline & Corvus splendens & $29(26.47-31.53)$ & $17(14.47-19.53)$ \\
\hline & Zosterops palpebrosus & $23(21.48-24.52)$ & $15(13.48-16.52)$ \\
\hline & Acridotheres gingnianus & $34(31.98-36.02)$ & $21(18.98-23.02)$ \\
\hline & Turdoides & $11(08.47-13.53)$ & $08(05.47-10.53)$ \\
\hline & Phoenicopterus roseus & $15(13.48-15.52)$ & $07(05.48-08.52)$ \\
\hline & Lophura leucomelanos & $18(15.98-20.02)$ & $13(10.98-15.02)$ \\
\hline & Perdicula asiatica & $12(09.47-14.53)$ & $05(02.47-07.53)$ \\
\hline & Francolinus pondiceriianus & $37(35.48-38.52)$ & $24(22.48-25.52)$ \\
\hline & Alectoris chukar & $16(13.98-18.02)$ & $10(07.98-12.02)$ \\
\hline & Coracias garrulus & $07(04.47-09.53)$ & $02(00.48-03.52)$ \\
\hline & Ciconia ciconia & $11(08.98-13.02)$ & $05(02.98-07.02)$ \\
\hline & Streptopelia orientalis & $17(14.98-19.02)$ & $09(06.98-11.02)$ \\
\hline & Streptopelia chinensis & $30(27.47-32.53)$ & $18(15.47-20.53)$ \\
\hline & Streptopelia turtur & $41(38.47-43.53)$ & $32(29.47-34.53)$ \\
\hline & Columba hodgsonii & $13(11.48-14.52)$ & $04(02.48-05.52)$ \\
\hline & Columba palumbus & $29(26.98-31.02)$ & $15(12.98-17.02)$ \\
\hline \multirow[t]{9}{*}{ MAMMALS } & Naemorhedus Goral & $41(39.48-42.52)$ & $30(28.48-31.52)$ \\
\hline & Capra aegagrus & $11(08.98-13.02)$ & $02(00.48-03.52)$ \\
\hline & Ovis ammon & $15(12.47-17.53)$ & $06(03.47-08.53)$ \\
\hline & Canis aureus & $59(56.47-61.53)$ & $40(37.47-42.53)$ \\
\hline & Herpestes edwardsii & $21(19.48-22.52)$ & $13(11.48-14.52)$ \\
\hline & Lepus negricollis & $27(24.98-29.02)$ & $22(19.98-24.02)$ \\
\hline & Macacca mulatta & $80(77.47-82.53)$ & $57(54.47-59.53)$ \\
\hline & Hystrix indica & $31(28.98-33.02)$ & $20(17.98-22.02)$ \\
\hline & Chiroptera & $17(15.48-18.52)$ & $06(04.48-07.52)$ \\
\hline
\end{tabular}

Particularly in marbles mining, where the extraction of very large size stone occur, is done by the explosion of great amount of dynamite etc. which creates high frequency of sound including vibration. This explosion as a result have devastating consequences in term of permanent migration of animals particularly mammals including Markhor, Goral, and other wildlife also. Environmental change may lead to different changes in living biota of ecosystem, mining is one of the major factors of the environmental changes. Mining blasts produce sound with high frequency the sound can produce disturbance in mode of life. Mining blasts produce serious problems in ecosystems, animals are highly sensitive to blasting the animals become near to leave its habitat due to the diminishing of food source. the blasting cause reproductive isolation in animals through which animals adopt to different environment, and may the animals be expose to different predators because of this the viability of animals become decrease in ecosystem. Through high anthropogenic activity most of the animals become migratory and highly expose to predators. (Shahsavari et al., 2019).

In developed organisms' Avian creature is greatly sensitive to anthropogenic disturbances. In ecosystem consequently bird's loss their permanent habitat and they migrate to sites far away from mining sites to avoid this disturbance. Seldom, some higher organisms cannot 
Table 7. This table shows statistical analysis of wild animals In District Mohmand.

\begin{tabular}{|c|c|c|c|}
\hline \multicolumn{4}{|c|}{ DISTRICT MOHMAND } \\
\hline & NAME & $\begin{array}{l}\text { MEAN(95\% CONFIDENCE } \\
\text { INTERVAL) (C) }\end{array}$ & $\begin{array}{l}\text { MEAN(95\% CONFIDENCE } \\
\text { INTERVAL) (M) }\end{array}$ \\
\hline \multirow[t]{9}{*}{ BIRDS } & Dicrurus macrocerus & $49(47.48-50.52)$ & $32(30.48-33.52)$ \\
\hline & Pycnonotus leucogenys & $55(52.98-57.02)$ & $38(35.98-40.02)$ \\
\hline & Turdoides plebejus & $62(59.47-64.53)$ & $34(31.47-36.53)$ \\
\hline & P. coeruleocephala & $43(41.48-44.52)$ & $31(29.48-32.52)$ \\
\hline & Francolinus pondicerianus & $60(57.98-62.02)$ & $53(50.98-55.02)$ \\
\hline & Turdoides caudata & $52(49.47-54.53)$ & $45(42.47-47.53)$ \\
\hline & Egretta gularis & $57(55.48-58.52)$ & $43(41.48-44.52)$ \\
\hline & Egretta dimorpha & $64(61.98-66.02)$ & $52(49.98-54.02)$ \\
\hline & Vanellus indicus & $84(81.47-86.53)$ & $65(62.47-67.53)$ \\
\hline \multirow[t]{4}{*}{ REPTILES } & Saara hardwickii & $42(40.48-43.52)$ & $23(21.48-24.52)$ \\
\hline & Eutropis dissimlis & $35(32.98-37.02)$ & $18(15.98-20.02)$ \\
\hline & Chalcides ocellatus & $26(23.47-28.53)$ & $09(06.47-11.53)$ \\
\hline & Caltotes versicolor & $32(30.48-33.52)$ & $11(09.48-12.52)$ \\
\hline \multirow[t]{2}{*}{ MAMMALES } & Vulpes vulpes & $56(53.98-58.02)$ & $27(24.98-29.02)$ \\
\hline & Chiroptera & $28(25.47-30.53)$ & $16(13.47-18.53)$ \\
\hline
\end{tabular}

tolerate such high frequency sound which may be beyond of their tolerance expectation appear dangerous in the form that organism may lose their young one immature or dead. The loss of young one is the most serious threat to the decrease of precious wildlife population. With the passage of time the constant loss may lead to extinction. It is obvious that in current times these mining plants greatly boost the economy of a country, but its harmful effects also cannot be ignored. The most serious impact is appeared on biodiversity in the form of loss of habitat, due to migration of animals, due to land infertility. As some organisms are highly connected with plants, vegetation, and forest. But unfortunately, ecosystem have loss these essential factors by developing roads, which leads to mining sites followed by huge trucks etc. which may be responsible for most accident of wildlife, while crossing these roads. In this way the population of precious wildlife decrease (Thomas et al., 2014).

Ecosystem is currently undergoing rapid changes the potential to exhibit serious damage on the health of wildlife and humans. The increasing rate of disease may be a serious indication that population are narrow. The results of our research in mining areas revealed that biodiversity, richness, and abundance were found to be limited by direct and indirect research in study areas. Which are close to mining sites in specific range in which the sound of explosion is effective. Interestingly the spices number were found high in area which are taken in a control in which the mining activities were lowest or on small scale. The species abundance and richness were found highest in area that were far away by a specific range of mines. Those consequences suggest that mining and related sports have a large effect at the distribution and numbers of wildlife.

\section{Conclusion}

Habitat destruction and hunting are major threats to wildlife. Local animals depend on the local jaws as they are the only source of food and shelter. The degradation of flora results in the death if fauna. Mining pushes, the fauna of concerned area towards extinction. Consequently, the human presence in the mining area multiplies the human urge to hunt and human settlement. Pollution is another major factor responsible for water contamination. Food chains disperse the heavy metal intake evenly the fauna and flora ending the biodiversity at the brink of extinction and disaster. The heavy metals accumulated in water absorbed by the plants roots and finally became the part of plant leaf and other different organs composition, animals including birds feed upon the leaves, seeds of trees. These metals target kidney liver etc. conclusively, mining and its associated activities i.e., hunting, pollution (Land, Air, and water), excavation of heavy metals, soil degradation and habitat loss are the major threats to wildlife.

\section{References}

AKBARI, M., MAHMOODI, K. and VAGHEFI, M., 2018. A comparison among data mining algorithms for outlier detection using flow pattern experiments. Scientia Iranica, vol. 25, no. 2, pp. 590-605. 
ALI, Z. and BIBI, F., 2013. Measurement of diversity indices of avian communities at Taunsa Barrage Wildlife Sanctuary, Pakistan. The Journal of Animal E Plant Sciences, vol. 23, no. 2, pp. 469-474.

BLOCH, K., JOHNSON, L.F., NKOSI, M. and EHRLICH, R., 2018. Precarious transition: a mortality study of South African exminers. BMC Public Health, vol. 18, no. 1, pp. 862. http://dx.doi. org/10.1186/s12889-018-5749-2. PMid:29996801.

BOENTE, C., ALBUQUERQUE, M.T.D., GERASSIS, S., RODRÍGUEZVALDÉS, E. and GALLEGO, J.R., 2019. A coupled multivariate statistic, geostatistical and machine-learning approach to address soil pollution in a prototypical $\mathrm{Hg}$-mining site in a natural reserve. Chemosphere, vol. 218, pp. 767-777. http:// dx.doi.org/10.1016/j.chemosphere.2018.11.172. PMid:30508795.

CAMPOS-CERQUEIRA, M. and AIDE, T. M., 2016. Improving distribution data of threatened species by combining acoustic monitoring and occupancy modelling. Methods in Ecology and Evolution, vol. 7, no. 11, pp. 1340-1348. http://dx.doi. org/10.1111/2041-210X.12599.

DEMKOVÁ, L., ÁRVAY, J., BOBULSKÁ, L., TOMÁŠ, J., STANOVIČ, R., LOŠÁK, T., HARANGOZO, L., VOLLMANNOVÁ, A., BYSTRICKÁ, J., MUSILOVÁ, J. and JOBBÁGY, J., 2017. Accumulation and environmental risk assessment of heavy metals in soil and plants of four different ecosystems in a former polymetallic ore mining and smelting area (Slovakia). Journal of Environmental Science and Health. Part A, Toxic/Hazardous Substances E'Environmental Engineering, vol. 52, no. 5, pp. 479-490. http://dx.doi.org/10.1 080/10934529.2016.1274169.

GARCIA, L.P.F., LEHMANN, J., DE CARVALHO, A.C.P.L.F. and LORENA, A.C., 2019. New label noise injection methods for the evaluation of noise filters. Knowledge-Based Systems, vol. 163, pp. 693-704. http://dx.doi.org/10.1016/j.knosys.2018.09.031.

GHOLIZADEH, A., CARMON, N., KLEMENT, A., BEN-DOR, E. and BORU゚VKA, L., 2017. Agricultural soil spectral response and properties assessment: effects of measurement protocol and data mining technique. Remote Sensing, vol. 9, no. 10, pp. 1078. http://dx.doi.org/10.3390/rs9101078.

HUFFMAN, J.A., PÖSCHL, U., MARTIN, S.T., SINHA, B., CHEN, Q. GUNTHE, S.S., BORRMANN, S., FARMER, D.K., GARLAND, R.M., HELAS, G. and JIMENEZ, J.L., 2010. Rainforest aerosols as biogenic nuclei of clouds and precipitation in the Amazon. Science, vol. 329, no. 5998, pp. 1513-1516.

JADAV, H. and THAKAR, K., 2018. Mining negative association rules in distributed environment. city: publisher.

KALANTAR-ZADEH, K., OU, J.Z., DAENEKE, T., MITCHELL, A., SASAKI, T. and FUHRER, M.S., 2016. Two dimensional and layered transition metal oxides. Applied Materials Today, vol. 5, pp. 73-89. http:// dx.doi.org/10.1016/j.apmt.2016.09.012.

LAAOUIDI, Y., BAHMED, A., NAYLO, A., EL KHALIL, H., OUVRARD, S., SCHWARTZ, C. and BOULARBAH, A., 2020. Trace elements in soils and vegetables from market gardens of urban areas in
Marrakech City. Biological Trace Element Research, vol. 195, no. 1, pp. 301-316. PMid:31392540.

MATTHEWS, B., DAS, S., BHADURI, K., DAS, K., MARTIN, R. and OZA, N., 2013. Discovering anomalous aviation safety events using scalable data mining algorithms. Journal of Aerospace Information Systems, vol. 10, no. 10, pp. 467-475. http://dx.doi. org/10.2514/1.I010080.

MOCHALOVA, L., SOKOLOVA, O., and YURAK, V., 2019. Logistics system of waste management at the mining enterprises. Journal of Environmental Management E Tourism, vol. 10, no. 1, pp. 202-209. https://doi.org/10.14505//jemt.10.1(33).20.

NOURI, M. and HADDIOUI, A., 2016. Human and animal health risk assessment of metal contamination in soil and plants from Ait Ammar abandoned iron mine, Morocco. Environmental Monitoring and Assessment, vol. 188, no. 1, pp. 6-12. http:// dx.doi.org/10.1007/s10661-015-5012-6. PMid:26631396.

WORLD WILDLIFE FUND - WWF. 2020 [viewed 22 January 2021]. Pangolin Species Report 2019-20 [online]. WWF. Available from https://www.worldwildlife.org/species/pangolin.

SHAHSAVARI, A., TABATABAEI YAZDI, F., MOOSAVI, Z., HEIDARI, A. and SARDARI, P., 2019. A study on the concentration of heavy metals and histopathological changes in Persian jirds (Mammals; Rodentia), affected by mining activities in an iron ore mine in Iran. Environmental Science and Pollution Research International, vol. 26, no. 12, pp. 12590-12604. http://dx.doi. org/10.1007/s11356-019-04646-9. PMid:30852753.

SINGH, G. and KAMAL, R.K., 2017. Heavy metal contamination and its indexing approach for groundwater of Goa mining region, India. Applied Water Science, vol. 7, no. 3, pp. 1479-1485. http:// dx.doi.org/10.1007/s13201-016-0430-3.

SONTER, L.J., ALI, S.H. and WATSON, J.E.M., 2018. Mining and biodiversity: key issues and research needs in conservation science. Proceedings of the Royal Society B, vol. 285, pp. 20181926. https://doi.org/10.1098/rspb.2018.1926.

STEPHEN, O., SAIN, M., MADUH, U.J. and JEONG, D.U., 2019. An efficient deep learning approach to pneumonia classification in healthcare. Journal of Healthcare Engineering, vol. 2019, pp. 4180949. http://dx.doi.org/10.1155/2019/4180949. PMid:31049186.

THOMAS, R., GOMARIZ, A., CAMPOS, M. and FOURNIER-VIGER, P., 2014. Fast vertical mining of sequential patterns using cooccurrence information. In: V.S. TSENG, T.B. HO, Z.H. ZHOU, A.L.P. CHEN and H.Y. KAO, eds. Advances in Knowledge Discovery and Data Mining. PAKDD 2014. Lecture Notes in Computer Science. Cham: Springer, pp. 40-52. https://doi.org/10.1007/978-3319-06608-0_4.

TREGUBOVA, P., KOPTSIK, G. and STEPANOV, A., 2019. Remediation of degraded soils: effect of organic additives on soil properties and heavy metals' bioavailability. IOP Conference Series: Earth and Environmental Science, vol. 368, no. 1, pp. 012054. http:// dx.doi.org/10.1088/1755-1315/368/1/012054. 